\title{
Purism, variation, change and 'authenticity': Ideological challenges to language revitalisation
}

\author{
Julia Sallabank \\ SOAS University of London
}

\section{Abstract}

This paper is based on recent research into the small, highly endangered language Giernesiei ${ }^{1}$ (Guernsey, Channel Islands). ${ }^{2}$ Language documentation has found unexpectedly rich variation and change in Giernesiei usage, not all of which can be accounted for by regional and age-related factors. At the same time, our research into language ideologies and efforts to maintain and revitalise Giernesiei have revealed deep-seated purist or 'traditionalist' language attitudes which resist and deny language change. This nostalgic view of language and culture can hyper-valorise 'authentic' traditions (arguably reinvented: Johnson 2013) and can lead to reluctance to share Giernesiei effectively with younger generations who might 'change the language', despite an overt desire to maintain it. This mismatch between ideologies and practices can be seen at language festivals, in lessons for children, and in the experiences of adult learners who were interviewed as part of a British Academy-funded project. I present a taxonomy of reactions to variation in Giernesiei, which confirms and extends the findings of Jaffe (2008) in Corsica. I also discuss recent revitalisation efforts which try to bring together older and 'new' speakers and promote the role of adult learners and 're-activate' semi-speakers. The findings support the view that full evaluation of language vitality should include documenting the processes and ideologies of language revitalisation (Sallabank 2012; Austin and Sallabank 2014).

\section{Guernsey: sociolinguistic background}

The island of Guernsey is the second largest of the Channel Islands, in the English Channel. Although the islands are located near the coast of Normandy (France), politically they are British Crown Dependencies: they owe allegiance to the British Monarch, but are not part of the United Kingdom or European Union. The Channel Islands are divided into two polities called Bailiwicks: the largest island, Jersey, forms one, while the other islands in the archipelago come under the Bailiwick of Guernsey. Each Bailiwick has its own parliament (called States), and are self-governing with regard to most matters apart from defence.

Each Channel Island has its own indigenous former vernacular, all of which are now highly endangered: Auregnais, the language of Alderney, the northernmost island, has had no fluent speakers since the mid-20 $0^{\text {th }}$ century, while Serquiais (Sark) may have only 10-12 remaining speakers.

\footnotetext{
${ }^{1}$ The name of the language has been spelt in numerous ways: Giernesiei / Dgernesiais / Guernesiais / Guernésiais / Djernezié, etc. This paper uses the Progressive Learner Spelling that the author and local researcher Yan Marquis have developed to aid pronunciation and learning (Sallabank and Marquis 2017). ${ }^{2}$ The research was carried out in collaboration with local researcher and language teacher Yan Marquis, to whom I am indebted for information, discussions and insights.
} 
This is the accepted version of an article published by Cambridge University Press in European

Review. Published version available from: https://doi.org/10.1017/S1062798717000400

Accepted version downloaded from SOAS Research Online: http://eprints.soas.ac.uk/25200/

These languages are varieties of Norman, one of the Oïl language family of northern France.

Language activists, language planners and politicians now promote and support the island varieties as languages in their own right. The indigenous language of Guernsey, Giernesiei / / d3ErnEzje I / is not officially recognised despite the launch of a government-supported Language Commission in 2013.

The majority language in Guernsey is now English, and has been since the early 20th century (longer on the more urbanised East coast). There is a history of diglossia with French, which was the High language from the $16^{\text {th }}$ to $19^{\text {th }}$ centuries; due to this, there is a point of view that Channel Island Norman languages are 'mere' dialects of French, although mutual intelligibility is low. French still retains strong prestige, which affects attitudes and usage among speakers and learners of Giernesiei. Although Giernesiei has been seen as a low-status variety for the last 500 years, as its vitality declines there is growing interest and positive attitudes, especially among non-speakers, which have led to increased desire to learn or make use of some Giernesiei.

Based on information gathered while conducting language documentation, the author and collaborators estimate that there are currently only a couple of hundred fluent native speakers of Guernsey's indigenous language remaining, mostly aged 80 years or older (out of a total island population of over 63,000 ). At the time of writing, the author is aware of only ten speakers under the age of 65 who are able to hold a sustained, impromptu conversation on a range of topics (this is our ad hoc test of proficiency: as there is no full linguistic description, there are no formal tests). All the current speakers are bilingual or dominant in English. ${ }^{3}$ Given that the vast majority of speakers are over the age of 70 , and that there are no proficient speakers under the age of 45 , it is not surprising that Giernesiei is often associated with a bygone age, by both speakers and non-speakers.

For people who are opposed to supporting language revitalisation, the rapid decline in language vitality is tantamount to proof that Guernsey's indigenous language is obsolescent (in both its linguistic and general senses) and not worth bothering with. In addition to this unsympathetic viewpoint, some older islanders (including native speakers and semi-speakers) have a nostalgic view of Giernesiei as 'the language of their youth', whose loss they are 'mourning'. Although they are sad to lose it, it is seen as a language of the past which, by implication, no longer has currency, and will not and cannot be maintained. In this idealised, nostalgic perception, Giernesiei is also static and unchangeable. Comments such as 'We speak just like our grandparents', or 'We speak the language of William the Conqueror ${ }^{4}$ illustrate this notion of language as unalterable heritage.

In the only census to survey speaker numbers (in 2001), 1327 people reported speaking Giernesiei fluently (2.22\% of the population). Of these, $70.4 \%$ (934) were over the age of 64 in 2001 . As discussed in Marquis and Sallabank (2013; 2014), this demographic means that native speaker numbers have fallen sharply in the intervening years. The census responses may even over-estimate levels of fluency, for reasons which are related to the issue of authenticity discussed in this paper. In our documentary research we have found numerous speakers not to be as fluent as they thought,

\footnotetext{
${ }^{3}$ One positive development is that one of the youngest adult speakers has a small child who is being raised in both English and Giernesiei.

${ }^{4}$ The Channel Islands were part of Normandy at the time of the Norman conquest of England in 1066; some islanders therefore consider England to be their oldest possession. Although it could be seen as an expression of pride, this phrase is usually used to stress the unchanging nature of Giernesiei.
} 
This is the accepted version of an article published by Cambridge University Press in European

Review. Published version available from: https://doi.org/10.1017/S1062798717000400

Accepted version downloaded from SOAS Research Online: http://eprints.soas.ac.uk/25200/

especially when asked to produce language outside their day-to-day 'comfort zone' of fairly formulaic conversational gambits on a limited range of topics. We surmise that in the census, some respondents equated the category of 'fluent speaker' with being a 'native speaker', which is interpreted as having been brought up in a home where Giernesiei was (one of) the language(s) of socialisation. However, many of these elderly 'native speakers' have few interlocutors, now use Giernesiei infrequently in very restricted domains, and find it difficult to speak it without preparation. As discussed below, many of those who consider themselves native (and therefore fluent) speakers might thus be classified by linguists as semi-speakers (Dorian 1977, Grinevald and Bert 2011). There are very few fully fluent speakers of Giernesiei left.

\section{Language variation and change in an endangered language}

Linguists are aware that language variation and change is endemic and unavoidable (e.g. Aitchison 1981). Indeed, endangered languages have been found to change more rapidly than fully vital ones (Trudgill 1983; Dorian 1989; Jones and Singh 2002). But as the quotations in the previous section indicate, lay people do not always accept the reality of language change. There is a paradox that purist ideologies of authenticity and correctness persist, and even strengthen, in the face of observable language change and fragmentation (Ferguson and Sallabank 2011). In Guernsey linguistic purists are termed 'traditionalists'.

In Giernesiei we find a range of variants of different kinds:

1. What we term 'iconic' variation, especially the standard division of regional dialects into two main groups: the West, known as the haut pas or high parishes, and the bas pas or lower parishes in the North. ${ }^{5}$ The following quotation from an interviewee illustrates these stereotypes, and is typical of opening remarks in documentary interviews.

[P] li dmeurei justmau shu bor-là à Saïnt Pierre et wecqé j'di mé d'io biocqé dmeurei là et [P] dmeurei là j'di d'io et i di d'iao.

[P] lived just over there in St Peter's and whereas I say /jo/ [water] although I lived here and [P] lived there I say /jo/ and he says/jas/.

2. This can be contrasted with the more complex regional variation that our documentation is revealing. It is possible to tell the origin of a native speaker of Giernesiei to within a kilometer or so; such regional variations are often equated with local administrative areas or parishes. But as Mari Jones (p.c.) has pointed out, parish boundaries are not isoglosses, and we have found variants which do not match the iconic assumptions about Northern versus Western features, especially in the area of Castel, which exhibits features of both regions as well as some unexpected ones such as /e $\sim$ aI / as in /tet/ tart / [head].

\footnotetext{
${ }^{5}$ These terms reflect the island's topology and have nothing to do with the sociolinguistic terms 'High' and 'Low'. The island is triangular in shape, and the south-eastern varieties of Giernesiei are no longer extant.
} 
This is the accepted version of an article published by Cambridge University Press in European

Review. Published version available from: https://doi.org/10.1017/S1062798717000400

Accepted version downloaded from SOAS Research Online: http://eprints.soas.ac.uk/25200/

3. 'Family-lects' and 'variations of variation in a small place' (Dorian 1994) whose influence or source are unclear.

4. Age-related variation: e.g. non-use of the subjunctive mood (Ferguson 2012); or conflation of savé (to know a fact) and counite (to know a person or place) (Jones 2002).

- Younger speakers (aged in their 60s and 70s) may also deconstruct elided forms, e.g.

Si intereisi a lei motao [I'm interested in cars] instead of the more traditional Si intereisi ei motao.

- Collapse or shift in the paradigms of reflexive verbs: e.g. s'autsié [to mind]:

M'autsie paa ${ }^{6}$ [I don't mind]

M'autsie tu? [Do you mind?] instead of T'autsie tu? as might be expected if French is used as a model (see below).

5. There are also contact features, which include lexical borrowing, phonetic changes, and pattern borrowing, for example the following trends cited by Jones (2002):

- The use of verbs in ways which are homonyms in English but not in French, e.g. saver, 'to know' (a fact) for 'to know' (a person or language); and run or make:

L'éghise é couraïe par la paraesse

The church is run by the parish (Jones 2002)

Mau vei paa daot té supportai

I won't support you any more (my data)

- Calques with prepositions: examples from my data include:

parlaï atour (chic shaoz)

to talk about (something)

I fao gardai haut lé Giernesiei

We must keep up Giernesiei.

- Jones (2002) also cites the use of tenses after 'when' as a sign of convergence with English, as it follows patterns used in English (e.g. cae tu viau 'when you come') rather than patterns more similar to French (e.g. quand tu viendras, 'when you will come'). This will be discussed further in 2.1 .

It can of course be difficult to pinpoint the cause of particular changes or variants, as there may be several contributory factors. Giernesiei is predominantly an oral language, and most speakers have no formal knowledge of its structure. In addition, infrequent use leads to attrition, especially of less

\footnotetext{
${ }^{6}$ Giernesiei speakers often drop the first person pronoun
} 
This is the accepted version of an article published by Cambridge University Press in European

Review. Published version available from: https://doi.org/10.1017/S1062798717000400

Accepted version downloaded from SOAS Research Online: http://eprints.soas.ac.uk/25200/

frequently used forms; these may even include the present tense of verbs, as older speakers have a tendency to speak mainly about events in the past.

\subsection{Reactions to language variation and change}

With regard to regional variation, Giernesiei can be seen as having historically been a polynomic language as defined by Marcellesi (1986; 2003; see also Jaffe 2008; Sallabank 2010a), until intergenerational transmission was broken. Among older speakers, respect for regional variation is combined with a perception of Giernesiei as a unified, distinct language. Iconic regional variants such as /o/ /av/ are a core value for many traditional speakers. However, more complex regional variation such as that described in category 2 above is often ignored as not fitting the iconic paradigm.

Nevertheless, regional variation can also be seen as a barrier to official recognition and standardisation: the same iconic variants /o/ /av/ are also frequently cited as reasons why Giernesiei 'can't be written' (despite a body of literature dating from the $19^{\text {th }}$ century onwards) and is therefore 'not a proper language' which cannot be taught as a timetabled school subject. ' Traditional regional variations may eventually disappear in the process of language loss and revitalisation.

Categories 4 and 5 above represent the kinds of variation associated with linguistic insecurity in semi-speakers. Many islanders who consider themselves native speakers of Giernesiei are actually 'semi-speakers' in the typology of Grinevald and Bert (2011; see also Dorian 1977 and Marquis and Sallabank 2013). Imperfect acquisition and attrition lead to linguistic insecurity and to increased reliance on French to fill gaps in knowledge of Giernesiei, especially in formal situations such as school lessons and cultural performances, which are the main language promotion activities (see section 3 below). The perceived status of 'native' speaker confers a degree of linguistic authority which is deferred to by people who consider their own proficiency to be lower, to the extent that it is difficult for a 'native' speaker to acknowledge gaps in their linguistic expertise, either consciously or unconsciously.

'Native' speakers consider their version (or image) of Giernesiei to be 'authentic', especially in comparison to the language produced by 'new' speakers (Sallabank and Marquis, forthcoming). A further concomitant of equating 'fluent speaker' with 'native speaker' is that it is very difficult for a non-native or new speaker to be considered fluent or authentic.

A further category of Giernesiei speaker which emerged in late 2016 is that of 'latent speakers' (in the terms of Basham and Fathman 2008) who are re-activating their linguistic competence, in some cases after not speaking Giernesiei for 50 years. This is a result of situations such as those related by a relatively large proportion of my research informants, where parents used Giernesiei among themselves, but not with their children; others reported having spoken Giernesiei until they started school, where it was discouraged, either overtly or implicitly. In many endangered language contexts latent speakers constitute a reservoir of untapped language knowledge. An informal group of these self-styled 'Rememberers' ${ }^{8}$, mainly aged 55-70 years, is making substantive efforts to improve

\footnotetext{
${ }^{7}$ Since 2004 extra-curricular lessons have been run informally in approximately half of the island's primary schools, but there are no moves to make these lessons official (see section 3 )

${ }^{8}$ It is interesting to note that members of this informal group prefer the name 'Rememberers', although in the terms of Grinevald and Bert (2011), 'rememberers' have less linguistic competence than semi-speakers. Group
} 
This is the accepted version of an article published by Cambridge University Press in European

Review. Published version available from: https://doi.org/10.1017/S1062798717000400

Accepted version downloaded from SOAS Research Online: http://eprints.soas.ac.uk/25200/

active fluency through conversation. As well as arranging to converse in Giernesiei with each other, they particularly seek opportunities to converse with 'native' speakers as the most desirable language models (see section 4).

The key difference between these two types of semi-speaker, which relates to language ideologies, is acknowledgement. 'Rememberers' recognise their lack of full active proficiency, which is a key difference between this group and 'native' speakers. At the same time, some latent speakers consider themselves to be more 'authentic' than new speakers with no previous experience of the language. In the current ideological climate in Guernsey, such nuances are highly salient, especially with regard to language change.

There is a general perception that older 'native' speakers' Giernesiei is the 'purest', despite observable language change and falling fluency levels (see Sallabank 2010b). Variants perceived as influenced by contact with English are perceived as age-related and are negatively sanctioned: when traditionalists talk about 'change' they generally mean influence from English, which is equated with deterioration. Meanwhile, variants influenced by French are perceived as prestigious, or are not noticed or acknowledged. The tradition which 'traditionalists' subscribe to includes the traditional diglossic prestige of French. Traditionalists, non-speakers and even some linguists tend to assume that French usage is 'correct' or 'traditional'.

In accordance with the hypervalorisation of elders' 'native speaker' status, variants produced by learners or new speakers are criticised and delegitimised by traditionalists. Comments such as 'We don't say it like that' or 'They'll never pronounce it like we do' can be demotivating for learners (see section 4 and Sallabank and Marquis, forthcoming). Measures that might make Giernesiei easier for learners or more attractive to young people, such as multimedia materials and pronunciation guidance, are dismissed as unnecessary.

Given Giernesiei's status as a 'language of the past', traditionalists perceive no need to expand the domains in which Giernesiei is used, and no need to develop new terminology: one older speaker commented that

In'yavei paa d'plane cae i palei Giernesiei

'There were no planes when they spoke Giernesiei'.

\section{Symbolic identity or revitalisation?}

Giernesiei is not part of the regular school curriculum, but since 2004 voluntary extra-curricular classes have been run informally in approximately half of the island's primary schools. These sessions run for half an hour a week during school terms (i.e. for a total of approx. 20 hours a year) and are taught mainly by retired people who are native and/or semi-speakers of Giernesiei. Supposed native speakers are seen as the best language teachers, although most have no training as teachers. The lessons have little coordination, no funding, few materials and no syllabus, so it is hardly surprising

members consider remembering to be a more active notion than passive or latent. Terms such as semi-, passive and latent speakers [like 'obsolescent' or 'moribund' languages] are felt to have negative connotations by community members, who prefer non-disparaging terminology. 
This is the accepted version of an article published by Cambridge University Press in European

Review. Published version available from: https://doi.org/10.1017/S1062798717000400

Accepted version downloaded from SOAS Research Online: http://eprints.soas.ac.uk/25200/

that children who attend them do not develop fluency in Giernesiei. The lessons are nevertheless popular and children enjoy them, but there is a high drop-out rate. Although these classes are presented as the way to 'save the language', their ineffectiveness in terms of language acquisition makes them largely symbolic in nature.

There are also adult language classes, some of which are held privately and some which are semi-official, run under the auspices of the Further Education College or the Guernsey Language Commission. ${ }^{9}$ Most are at beginner level; elementary and intermediate classes were held in the 1980s but only started to be offered again as recently as 2014. There are some individual success stories, but also a number of challenges for prospective new speakers, which will be discussed in the next section.

A relatively recent innovation is 'Speed Patois', organised by the Guernsey Language Commission, which brings together speakers of all levels of fluency with the intention of providing opportunities to practice. These informal evenings are usually held in pubs and follow the format of speed dating, in that participants move from table to table, with a five-minute limit on conversations. Although reactions to this initiative have been overwhelmingly positive, the format is not conducive to more advanced levels of conversation. The function of the Speed Patois sessions seems mainly to provide an enjoyable context for new and older or 'authentic' speakers to get to know each other; and to build the confidence of new, passive, semi or rusty speakers.

The other main focus of language-related activities is festivals, songs and concerts. Chief among these is the 'Guernsey-French' section of the annual Eisteddfod cultural festival. This is attended mainly by older speakers, and until fairly recently provided a significant forum for speaking and hearing Giernesiei publicly, both by performers and among the audience. In recent years, as the number of fluent older speakers able to take part decreases, an increasing number of learners and new speakers are taking part in the Beginners' and Intermediate classes. Ironically, this has led to a decrease in the amount of Giernesiei used at the event, since many participants learn their pieces by heart and are unable to speak or understand Giernesiei. There has also been a sharp increase in the number of children taking part, giving both group and individual recitals. Adjudicators therefore accommodate by speaking English.

The tone of the Eisteddfod is determinedly traditionalist: pieces for performance usually reflect what is perceived as traditional culture, and many participants dress up in old-fashioned clothes (although not usually in Guernsey's traditional costume, which is seen as too informal). It is a showpiece for Giernesiei as heritage, which is stated overtly by some adjudicators. Yet as noted by Johnson (2013), the traditions that it hyper-valorises are arguably reinvented; the festival was founded in 1921 and the Guernsey-French section was reinstated in 1985 after several decades in abeyance. Many of the songs performed are translated from English, as according to folk history Giernesiei songs and dances were wiped out by religious Puritanism in the $17^{\text {th }}$ century.

Such festivals increase the visibility/audibility of Giernesiei, for example through media coverage, and allow participants to express pride in the language, which is important for both prestige and

\footnotetext{
${ }^{9}$ This quasi-official body was founded by a member of the island parliament in 2013 with the aim of supporting bottom-up language revitalisation efforts through fundraising. Although it reflects growing support for maintaining Giernesiei, its initial promise has not yet been realised.
} 
This is the accepted version of an article published by Cambridge University Press in European

Review. Published version available from: https://doi.org/10.1017/S1062798717000400

Accepted version downloaded from SOAS Research Online: http://eprints.soas.ac.uk/25200/

personal confidence. But although the events are generally portrayed as language revitalisation activities, they are actually about performance of 'authentic' identity rather than language use or language proficiency. A parallel can be seen in Heinrich's (2005) discussion of the Ryukyuan languages of Okinawa, Japan. Heinrich observes that similarly to Guernsey, 'Revitalisation' activities often consist of 'speech contests, arts, entertainment, etc. ... the means of reversing language shift (e.g. speech contests) are frequently taken to be the end of language revitalisation.' (2005: 69)

The value of indigenous language as a marker of local identity is also being developed outside the traditional speaker community. A local jeweller has developed a range of jewellery inscribed with Giernesiei mottos such as:

L'amour a jomais (love for ever)

Vis tes saonges (live your dreams)

Lé maonde est t'n ormé (the world is your ormer ${ }^{10}$ )

$P^{\prime}$ tite Eteile (little star).

The Guernsey Language Commission has secured sponsorship by this jewellery company for a reliable translation service, most of whose work consists of providing short phrases similar to the above. The genres of the translations include wedding speeches, football club mottoes or chants, and tattoos, all of which indicate increasing interest in Giernesiei for 'place branding' and symbolic identity. The establishment of this translation service has improved the quality of the translations; prior to this, the non-communicative nature of the expressions meant that accuracy was not a completely necessary feature.

As Le Page and Tabouret-Keller (1985: 239-40) note, feelings of ethnic identity can survive total language loss, but language choices can form part of empowerment and agency in identity construction. On the other hand, Bankston and Henry (1998), discussing Louisiana French (which shares some features with Channel Island Norman), note that a strong identification with a minority language may not always correlate positively with language maintenance and use, particularly when it comes to transmitting a low-status variety to children; this has parallels in Guernsey (with some exceptions).

An alternative way of expressing language loyalty (or at least affection) is provided by Shandler's (2006) notion of 'postvernacular' rather than communicative use:

In the postvernacular mode, familiar cultural practices - reading, performing, studying, even speaking - are profoundly altered. Though it often appears to be the same as vernacular use, postvernacularity is in fact something fundamentally different in its nature and intent as a selective vocabulary sprinkled through the speech and as an object of affection. (Shandler 2006: 2)

Shandler goes on to claim that

\footnotetext{
${ }^{10}$ An edible shellfish and local delicacy; a pun and calque based on the English saying 'the world is your oyster'.
} 
This is the accepted version of an article published by Cambridge University Press in European

Review. Published version available from: https://doi.org/10.1017/S1062798717000400

Accepted version downloaded from SOAS Research Online: http://eprints.soas.ac.uk/25200/

Postvernacularity can be a liberating concept, prompting possibilities of language use other than the vernacular model of full fluency in an indigenous mother tongue. Thus, postvernacularity has important implications for the interrelation of language, culture and identity - indeed, for the notion of what might constitute a speech community (Shandler 2006: 4).

It also has important implications for what might constitute revitalisation. Thieberger (2002) argues that token language use may be adequate for image and identity purposes: 'language revival need not be an "all or nothing" venture'.

\section{Language ownership}

Between 2012 and $2014^{11}$ I interviewed 32 current and former learners of Giernesiei, a high proportion of the estimated total of approximately 40 learners taking adult classes at any given time. The commonest themes emerging from the responses were, firstly, lack of exposure and opportunities to practise, which are of course inherent in learning a highly endangered language where the number of fluent native speakers who are able to act as interlocutors is decreasing increasingly rapidly; and secondly, if and when learners can find older/native speakers to converse with, they often experience lack of encouragement from them:

'Lots of people see Giernesiei as a nostalgic thing and almost as a secret society or club with an audible membership card to belong to the community'

'I find people too quick to correct - as learners we're only at toddler stage'

'I don't like speaking in front of people who are really good for fear of making mistakes'

'When my neighbours found out I was learning they were enthusiastic, but they try to get one over by rapping something out like a machine gun - end of conversation.'

'Pops didn't feel it sounds right to hear a young person speaking it'

'Gran only talks to people she knows speak it ... she keeps it to herself, doesn't want to share'.

This reaction was not universal - there are supportive older speakers - but as the range of quotes above illustrates, it was both frequent and salient in the findings. Some learners reported being so discouraged by such reactions that they have stopped learning or speaking Giernesiei.

Both of the main themes mentioned by the learners interviewed can be, at least in part, attributed to the assumption that only 'native' speakers are worthwhile interlocutors for the purpose of providing authentic input. Yet despite the ongoing loss of the native speaker community, there is little evidence to date of learners, new speakers and 'Rememberers' organising to practise with each

\footnotetext{
${ }^{11}$ As part of a research project into learning small languages conducted in collaboration with Yan Marquis and funded by the British Academy.
} 
This is the accepted version of an article published by Cambridge University Press in European

Review. Published version available from: https://doi.org/10.1017/S1062798717000400

Accepted version downloaded from SOAS Research Online: http://eprints.soas.ac.uk/25200/

other, although this might provide a less challenging environment and more comprehensible input (in the terms of Krashen 1985).

We term this phenomenon 'language ownership' (Sallabank 2013; Sallabank and Marquis forthcoming), whereby 'native' and 'traditional' speakers think of themselves as authorities on language and 'owners' or 'guardians' (and gatekeepers) of 'traditional' Giernesiei. This is often expressed as concern about language change, in part because younger people can't be trusted to keep the language 'pure':

'No offence but I wouldn't say that you're good enough - that your Guernsey French is good enough to teach children - it's like the Ravigotteurs [former revitalisation group] you see, they're going to change the language to teach it - it won't be the Guernsey French we know.'

There is a tradition of the older generation being deferred to in questions of language 'correctness' and authority:

'I mean I can speak it but I'm not fluent like they were you know um I mean I do, I can learn it and eum on the whole I don't think my words are too bad but this year [a reference to the annual Eisteddfod] will be the trial because I've always had my parents to sort of tell me if I was saying it not right you know.'

It is therefore not surprising that 'elders' feel they should retain control of both language usage and language policy. Being a 'native speaker' is seen as more salient than frequency of use, teaching qualifications or experience. The result is failure to share the language effectively, since (subconsciously) effective learning might undermine traditional speakers' language ownership (Marquis and Sallabank 2014).

\section{Conclusions}

The observations discussed in this paper reveal what Marquis and Sallabank (2014) term a 'static' ideology of language, in which the indigenous language has a mainly nostalgic or post-vernacular value. The focus of language-related activities such as festivals and extra-curricular school lessons is on maintenance of the current language community, and its authority and legitimacy, rather than on development of new users or uses, which is Romaine's (2006) definition of language revitalisation.

In this analysis, I am using Woolard and Schieffelin's (1994) definition of ideology: '...ideologies envision and enact links of language to group and personal identity, to aesthetics, to morality, and to epistemology' (1994: 55-56). Spitulnik (1998) amplifies this as follows: 'language ideologies are, among many other things, about the construction and legitimation of power, the production of social relations of sameness and differences, and the creation of cultural stereotypes'. These definitions aptly describe the processes by which Giernesiei seems to be constructed increasingly as a post-vernacular symbol of identification rather than as a vehicle for communication: 'foregrounding the metacommunicative/pragmatic function of language use over referential function' (Ahlers 2006: 58). 
This is the accepted version of an article published by Cambridge University Press in European

Review. Published version available from: https://doi.org/10.1017/S1062798717000400

Accepted version downloaded from SOAS Research Online: http://eprints.soas.ac.uk/25200/

My PhD research, carried out between 2000 and 2005, found that among the native speaker community which at that time was still extant, Giernesiei was used primarily for phatic

communication, among friends and relatives, in mainly domestic domains. This domain shrinkage is typical the processes of language endangerment. It also seems to be typical of revitalisation movements that they try to shift the domains of use towards more formal, 'High' (in a diglossic sense) domains, especially through schools. Bruce (1999) suggests that movements such as religious sects tend to develop in predictable ways, akin to the developmental stages found in language acquisition (Lightbown and Spada, 2006). It may a developmental feature of language revitalisation movements that they need to go through the stage of campaigning to get their language taught in schools. It is therefore ironic that at the same time as relying on extra-curricular school lessons for language reproduction, traditionalist language supporters in Guernsey are unwilling to engage in corpus planning to develop the language's capacity to function in those domains, or to incorporate terms for items such as mobile phones and other digital devices, which form an intrinsic part of life for school-age students. It might be observed that the formal school environment, where teachers hold expertise and power, is well suited to an ideology where legitimacy is invested solely in 'native' speakers. Far from facilitating the transmission of the language to a new generation, it might be argued that the extra-curricular lessons mitigate against it by denying new speakers' empowerment. This is especially the case when teachers are untrained and were educated before the advent of communicative teaching techniques. ${ }^{12}$

It seems clear from the findings reported in this paper that ideologies of purism, 'authenticity' and 'ownership' contribute to the lack of new Giernesiei speakers progressing beyond beginner level. To an extent these ideologies have been internalised by learners and new speakers, as well as latent and semi-speakers, so that they too defer to the authority of traditional(ist) native speakers. However, given that family intergenerational transmission of Giernesiei ceased about 50 years ago (after declining for several decades before that), revitalisation (or revernacularisation from its post-vernacular state) is unlikely to succeed without the acceptance of new uses and users.

Post-vernacular language performance in Guernsey is usually connected with 'authentic', 'traditional' cultural expression. But post-vernacularity is not necessarily a negative influence on the empowerment of new speakers of endangered languages. Moore (2013: 4) suggests that it can help to deconstruct '(native) speakerism' by valorising less essentialist language practices. This involves a shift in focus 'away from (named) languages and (native) speakers as pre-theoretical givens to one oriented instead to internally differentiated speaker repertoires, and to linguistic resources deployed to various effects in various contexts of use'. The translations requested from the Guernsey translation service often take Giernesiei into new genres, but they do not necessarily any extension of the user's linguistic repertoires beyond the wearing of a T-shirt or tattoo. It is difficult to deploy linguistic resources that one does not have.

The lack of progression among learners, and the lack of communicative community use of Giernesiei, do not seem to be ringing alarm bells publicly in Guernsey, although the Language Commission is aware of the lack of effectiveness of peripatetic school lessons in teaching Jèrriais, the closely related

\footnotetext{
12 In some cases, older islanders had little access to education themselves. Some grew up before the full implementation of upper secondary education in rural areas (Crossan 2016); in other cases, education was interrupted by the German occupation of Guernsey from 1940 to 1945.
} 
This is the accepted version of an article published by Cambridge University Press in European

Review. Published version available from: https://doi.org/10.1017/S1062798717000400

Accepted version downloaded from SOAS Research Online: http://eprints.soas.ac.uk/25200/

language of the neighbouring island of Jersey. To date there has been no discussion in Guernsey regarding the aims of language revitalisation. It is therefore possible that Giernesiei may slip into a minimalised, symbolic, post-vernacular role without 'ideological clarification' (Fishman 1991) having taken place, and without motivations, implications and other options having been explored. Full evaluation of language vitality should therefore include documenting the linguistic repertoires, and practices and aims of new speakers, as part of the processes and ideologies of language revitalisation (Sallabank 2012; Austin and Sallabank 2014, forthcoming).

\section{References}

Ahlers, J. C. 2006. Framing Discourse. Journal of Linguistic Anthropology 16: 58-75.

Aitchison, J. 1981. Language change: Progress or decay. London: Fontana.

Austin, P.K. and Sallabank, J. (eds) 2014. Endangered Languages: Beliefs and Ideologies in Language Documentation and Revitalization. Oxford: Proceedings of the British Academy/Oxford University Press.

Austin, P.K. and Sallabank, J. Forthcoming. Language documentation and revitalisation: Partners or just good friends? Paper presented at British Association for Applied Linguistics Annual Conference, September 2014; in preparation for publication.

Basham, C. and Fathman, A. 2008. The Latent Speaker: Attaining Adult Fluency in an Endangered Language. International Journal of Bilingual Education and Bilingualism 11:577-597.

Bankston, C. L. I. and J. Henry 1998. The silence of the gators: Cajun ethnicity and intergenerational transmission of Louisiana French. Journal of Multilingual and Multicultural Development 19(1): 1-23.

Bruce, S. 1999. Sociology. Very Short Introductions. Oxford: Oxford University Press.

Crossan, R-M. 2016. The States and Secondary Education 1560-1970. Guernsey: Crossan.

Dorian, Nancy C. 1977. The problem of the semi-speakers in language death. Linguistics 191:23-32

Dorian, Nancy, ed. 1989. Investigating Obsolescence: Studies in Language Contraction and Death. Cambridge: Cambridge University Press.

Dorian, Nancy. 1994. Varieties of Variation in a Very Small Place: Social Homogeneity, Prestige Norms, and Linguistic Variation. Language 70:631-696.

Ferguson, Clare (2012). The Subjunctive in Guernsey French: Implications for Gauging Authenticity in an Endangered Language. Unpublished PhD thesis, University of the West of England, Bristol. 
This is the accepted version of an article published by Cambridge University Press in European

Review. Published version available from: https://doi.org/10.1017/S1062798717000400

Accepted version downloaded from SOAS Research Online: http://eprints.soas.ac.uk/25200/

Ferguson, Clare and Sallabank, Julia (2011). Ideologies of 'authenticity' in an endangered language: Change and 'correctness' in Guernsey French. Paper presented at the British Association for Applied Linguistics annual conference, Bristol, September 2011.

Fishman, Joshua A. 1991. Reversing language shift: Theoretical and empirical foundations of assistance to threatened languages. Bristol: Multilingual Matters.

Grinevald, Colette and Michel Bert (2011). Speakers and communities. In Peter K. Austin and Julia Sallabank (eds.): The Cambridge Handbook of Endangered Languages. Cambridge: Cambridge University Press, 45-65.

Hinton, Leanne. 1997. 'Survival of endangered languages: the Californian Master-Apprentice program', International Journal of the Sociology of Language 123: 177-91.

Jaffe, Alexandra. 2008. 'Language ecologies and the meaning of diversity: Corsican bilingual education and the concept of 'polynomie', in A. Creese, P. Martin and N. H. Hornberger (eds.), Encyclopedia of language and education, 2nd edn, Vol. IX: Ecology of Language. Berlin: Springer, 225-36.

Krashen, Stephen D. 1985. The Input Hypothesis. Issues and Implications. London: Longman.

Le Page R. B. and A. Tabouret-Keller 1985. Acts of identity: Creole-based approaches to language and ethnicity. Cambridge University Press.

Jones, Mari C. 2002. 'Mette a haut dauve la grippe des angllais': language convergence on the island of Guernsey. In Language Change: The Interplay of Internal, External and Non-linguistic Factors, eds. M. C. Jones and Edith Esch. Berlin: Mouton de Gruyter, 143-168.

Jones, Mari C., and Esch, Edith eds. 2002. Language change: The interplay of internal, external and non-linguistic factors. Berlin: Mouton de Gruyter.

Lightbown, P.M., and Spada, N. 2006. How Languages are Learned, 3rd edition. Oxford: Oxford University Press.

Marcellesi, J-B. 1986. 'Actualité du processus de naissance de langues en domaine roman', Cahiers de Linguistique Sociale 9: Sociolinguistique Romane. Rouen: University of Rouen. 21-9.

Marcellesi, J.-B., T. Bulot and P. Blanchet 2003. Sociolinguistique: Épistémologie, langues régionales, polynomie. Paris: L'Harmattan.

Marquis, Yan and Julia Sallabank (2013). Speakers and language revitalisation: a case study of Guernésiais (Guernsey). In Mari C. Jones and Sarah Ogilvie (eds): Keeping Languages Alive: Documentation, Pedagogy, and Revitalization. Cambridge: Cambridge University Press: 167-180.

Moore, Robert E. 2013. Discussion paper: 'Taking up speech' in an endangered language: Bilingual discourse in a heritage language classroom. King's College London Working Papers in Urban Language \& Literacies 112.

http://www.kcl.ac.uk/sspp/departments/education/research/ldc/publications/workingpapers/the-p 
This is the accepted version of an article published by Cambridge University Press in European Review. Published version available from: https://doi.org/10.1017/S1062798717000400 Accepted version downloaded from SOAS Research Online: http://eprints.soas.ac.uk/25200/ apers/wp112-moore-et-al-2013---taking-up-speech-in-an-endangered-language.pdf, accessed 4 April 2016.

Romaine, S. 2006. 'Planning for the survival of linguistic diversity', Language Policy 5(4): 441-73.

Sallabank, Julia (2010a). Standardisation, prescription and polynomie: can Guernsey follow the Corsican model? Current Issues in Language Planning 11/4, 311-330.

Sallabank, Julia (2010b). Endangered language maintenance and revitalisation: the role of social networks. Anthropological Linguistics 52/3: 184-205.

Sallabank, J. 2012. From language documentation to language planning: Not necessarily a direct route. Language Documentation \& Conservation Special Publication No. 3: Potentials of Language Documentation: Methods, Analyses, and Utilization, ed. F. Seifart et al.: 118-125. U. Hawai'i Press.

Sallabank, Julia and Yan Marquis (2017). Spelling trouble: Ideologies and practices in Giernesiei / Dgernesiais / Guernesiais / Guernésiais / Djernezié... (co-authored with Yan Marquis), in Jones, M. C. and D. Mooney (eds): Orthography Development for Language Maintenance and Revitalisation Sallabank, Julia and Yan Marquis (forthcoming). "We don't say it like that": language ownership and (de)legitimising the new speaker, in Smith-Christmas, C. and M. Hornsby (eds): Ideologies and Practices of New Speakers of Minority Languages. Basingstoke: Palgrave Macmillan.

Shandler, J. 2006. Adventures in Yiddishland: Postvernacular language and culture. Berkeley/Los Angeles: University of California Press.

Thieberger, N. 2002. Extinction in whose terms?, in Bradley, D. and M. Bradley (eds.), Language endangerment and language maintenance: An active approach. London: Routledge, pp.310-28 Trudgill, Peter. 1983. On Dialect: Social and Geographical Perspectives. Oxford: Blackwell. Woolard, K. and B. Schieffelin. 1994. Language Ideology. Annual Review of Anthropology 23: 55-82. 